\title{
Migration routes of four juvenile Imperial Eagles Aquila heliaca from the Baikal region of eastern Russia
}

\author{
MUTSUYUKI UETA and VITALY V. RYABTSEV
}

\section{Summary}

From 1950 to 1999 there was a substantial decrease in the number of Imperial Eagles Aquila heliaca breeding in the Baikal region of eastern Russia, but there have been no apparent changes in habitat or breeding success within this region. Identification of wintering and stopover sites is therefore necessary to discover whether negative impacts at these sites could be causing the observed population decline. To this end, we satellite-tracked four juvenile Imperial Eagles from Lake Baikal to their wintering grounds. Two sibling eagles were tracked in 1998 and two siblings from a different brood in 1999. The eagles migrated through eastern Mongolia and central Inner Mongolia (China), and wintered from south China to Thailand. Siblings independently used the same migration flyway, and the flyway was different between families. These results provide useful information for determining the causes of the decline in the population of Imperial Eagles in the Baikal region.

\section{Introduction}

Imperial Eagles Aquila heliaca breed in Central Europe, Turkey, east to Transbaikalia and Mongolia, and winter in eastern Africa, Arabia, and north India to eastern China. The eastern limit of the species' distribution is the Baikal Region, with the population here being separated from that of neighbouring Krasnoyarsk region by a wide $(600 \mathrm{~km})$ belt of taiga and the northern section of the Sayan Mountains (Ryabtsev 1999).

The worldwide population of Imperial Eagle is decreasing (Hallmann 1996, Petrov et al. 1996, Vetrov 1996) and the species is listed as Vulnerable under IUCN Red List criteria (BirdLife International 2000). Nevertheless, in Hungary the eagle population is increasing thanks to successful conservation efforts (Haraszthy et al. 1996), and from 1990 to 1999 nearly all Russian Imperial Eagle populations were stable (Bilik and Galushin 1999). However, the Baikal population showed a steep decline in numbers during this time period, and from 1950 to 1999 the number of Imperial Eagles in the Irkutsk Region (to the west of Baikal) decreased from 300 to 40 pairs (Ryabtsev 1999). In 1999 the Baikal population was estimated at 70-90 pairs (Ryabtsev 1999), while the population in Russia as a whole is estimated to be $870-1,280$ pairs, with $600-890$ pairs in European Russia and 270-390 in Siberia (Belik \& Galushin 1999).

From ancient times to today the "White-headed Eagle" (i.e. Imperial Eagle) 
has been considered a sacred bird of the Baikal Buryats (Ryabtsev 1984, 1997, 1998), and they have therefore traditionally been protected. As a result, there is no obvious reason for population declines, for example through changes in habitat or breeding success, within the Baikal region. To conserve the eagle populations it may therefore be crucial to know the wintering and stopover sites of eagles breeding in Baikal, and to then investigate whether those sites are undergoing any negative impacts. Identification of wintering sites and migration routes is one of the targets identified in BirdLife International (2000) to aid the conservation of the species.

The development of the satellite transmitter has greatly contributed towards the disclosure of migration routes of some eagle species (Meyburg and Lobkov 1994, Meyburg and Meyburg 1998, Ueta et al. 1998, 2000), and Meyburg et al. (1995) tracked Imperial Eagles in the west of their range. In this study, therefore, we investigated the migration routes and wintering sites of Imperial Eagles breeding in the Baikal region, using satellite transmitters.

\section{Methods}

Satellite transmitters (PTTs) were attached to nestling Imperial Eagles from two different nests: one at Pribaikalsky National Park, on the western coast of Lake Baikal on 5 August 1998; and a second on the shore of the Bratsk reservoir of the Angara River, $250 \mathrm{~km}$ to the west, on 29 July 1999. In both years, PTTs were attached to two nestlings from a single clutch. In 1998, PTT with ID 4130 was attached to the older nestling, and PTT ID 6754 to the younger nestling, and in 1999 PTT ID 6079 was attached to the elder nestling, and PTT ID 23367 to the younger nestling.

Satellite transmitters (model PTT T-2050) were made by the Nippon Telegraph and Telephone Corporation (NTT) and Toyo Communication Equipment Co. (TOYOCOM), with dimensions of $70 \times 34 \times 23 \mathrm{~mm}$, weighing $65 \mathrm{~g}$, including an antenna of $18 \mathrm{~cm}$. Detailed information about these PTTs is shown in Table 1. PTTs were harnessed to the backs of the eagles with Teflon-treated ribbons as described by Nagendran et al. (1994).

Location data were received through the Argos satellite system and were categorized into seven Location Classes (LC) that showed increasing accuracy, labelled Z, B, A, O, 1, 2 to 3 (ARGOS Inc. 1992). In general we used LC 1-3, which have a location error of less than $1 \mathrm{~km}$. LC o, A, B, Z data were used only when locations were spatially and temporally close to the location estimates preceding or following them. Distances between locations were calculated using the computer programme ELSA ver. 3 of CLS/Argos.

\section{Results}

Three Imperial Eagles were tracked successfully, one in 1998 and two in 1999. One transmitter in 1998 (ID 6754) ceased signalling in Inner Mongolia, China (Figure 1), but the remaining three transmitters continued signalling for the entire migration period.

In 1998, the older eagle began migrating on October 8 , while the younger eagle began on October 17, just after the first snowfall. Both eagles migrated south-east 


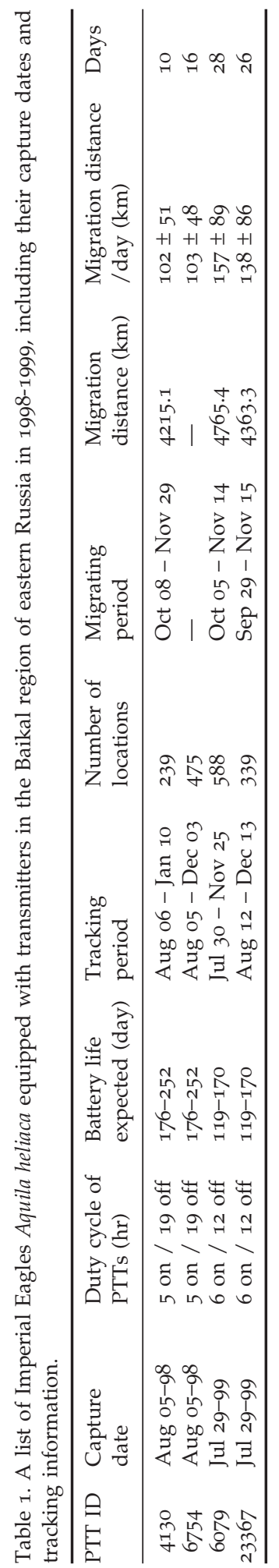



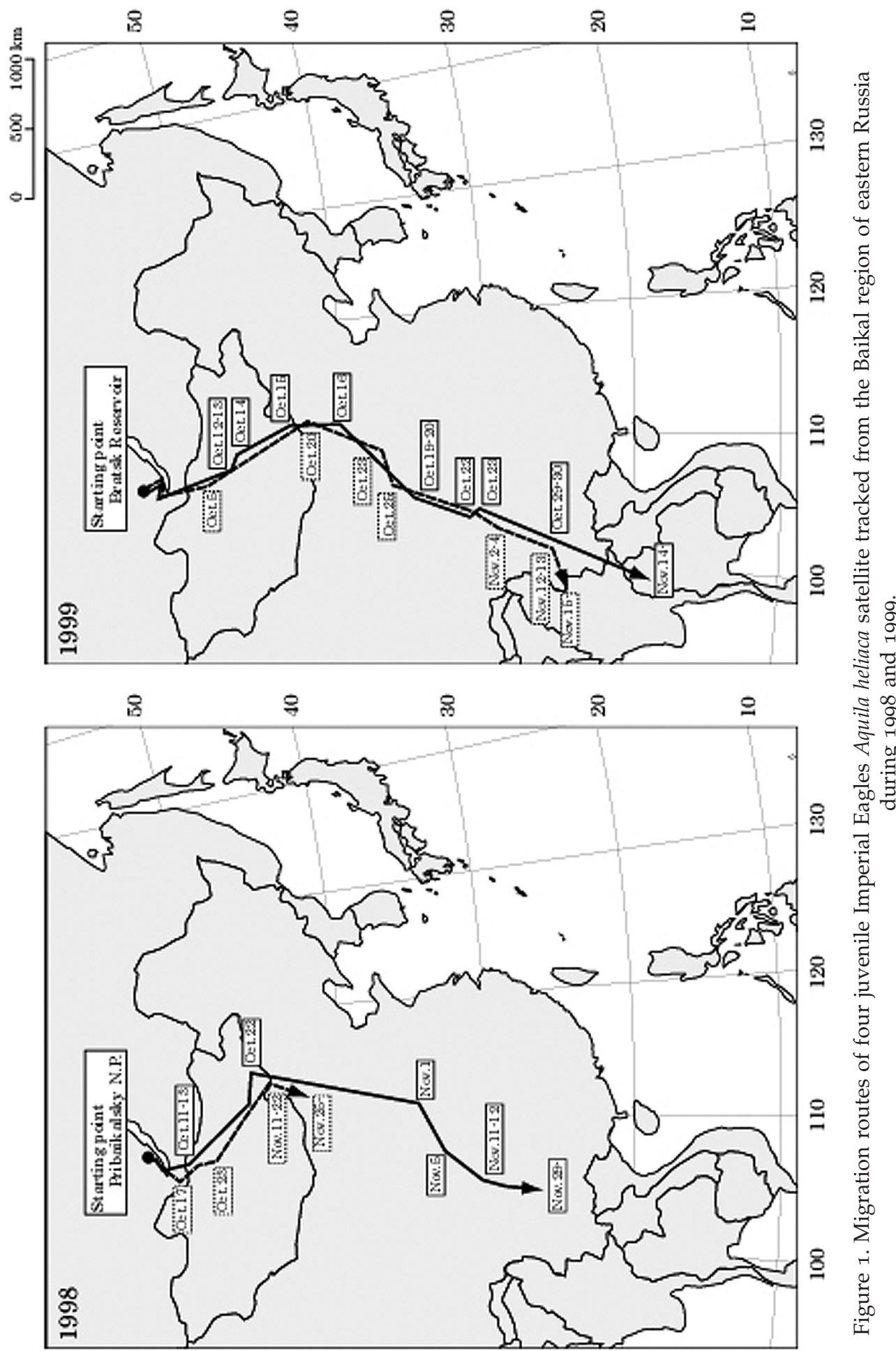
from their nest site and crossed snow-covered mountain ranges with altitudes of 1,500-2,200 $\mathrm{m}$. Their migration route appeared to avoid the Gobi Desert, and they turned SSW at a point in east Mongolia $(45.929 \mathrm{~N}, 114.329 \mathrm{E}$ for ID 4130 and 46.706-47.103N, 112.497-112.994E for ID 06754). One eagle's PTT (ID 6754) then failed $(42.708-43.276 \mathrm{~N}$, 111.926-112.313E). Another eagle wintered in Dongchuan, Yunnan Province, China (26.242-26.339N, 103.644-103.687E).

In 1999 the eagles started their migration on 29 September and 5 October. Both eagles started migration long before snowfall. They migrated SSE from their nest site and crossed the Gobi Desert before turning SSW at at point in central Inner Mongolia, China $(42.779-42.786 \mathrm{~N}$, 109.680-109.712E for ID 6079 and $41.727 \mathrm{~N}$, 109.375E for ID 23367). One eagle (ID 6079) wintered in northern Thailand (17.814-18.075N, 98.249-98.956E), and the other (ID 23367) in northeastern Myanmar $(23.907-23.997 \mathrm{~N}, 97.631-97.947 \mathrm{E})$.

Habitat information for the wintering area identified in 1998 indicated that the site is a hilly pine forest with wheat fields left fallow in winter. Agricultural chemicals are not used much, and few hunting activities take place in this area (Yang Xiaojun pers. comm.).

The mean migration distance/day is shown in Table 1 . The maximum migration distance/day was $175 \mathrm{~km}$ for ID 4130, $208 \mathrm{~km}$ for ID 6754, $483 \mathrm{~km}$ for ID 6079 , and $338 \mathrm{~km}$ for ID 23367 . ID 6079 and 23367 crossed the desert during their migration flyway, which was the maximum flyway distance.

We tracked sibling eagles from two nests. The siblings that we tracked in 1998 migrated independently: ID 4130 started it's autumn migration on 8 October and ID 6754 started it's migration on 17 October. Despite migrating separately they followed the same flyway. We tracked siblings from a different nest in 1999, which also migrated the same flyway independently. The flyways were different between the siblings tracked in 1998 and 1999.

\section{Discussion}

The three Imperial Eagles successfully satellite tracked from breeding sites in the Baikal Region migrated via eastern Mongolia and central Inner Mongolia (China) and wintered from south China to Thailand. Imperial Eagles breeding in the Ural mountains winter in Arabian desert areas (Meyburg et al. 1995), but Baikal's eagles appear to winter in mountain districts of South-East Asia, with a predominantly moist monsoon climate. The hypothesis that there was hunting activity and/or heavy use of agricultural chemicals at wintering and/or stopover sites was not supported by this study, at least in the wintering area identified in 1998. By collecting information from other sites on the migration routes identified in this study, further insight will be gained into the reasons behind the decline of the Baikal Imperial Eagle population. International cooperation throughout the eagle flyway (Russia to Thailand) will be necessary to conserve the eagle population.

This study also provided information on the migration strategies of Baikal's Imperial Eagles. Only one eagle started migration just after first snowfall, the other three starting before. Wood et al. (1998) suggests that dispersal in Bald Eagles Haliaeetus leucocephalus in Florida coincides with lack of food, while McClelland et al. (1996) suggests that lack of food is not the major inducement 
for migration in Bald Eagles in Montana. At the end of September and beginning of October there is usually no snow cover in the Baikal region, but most Siberian Gophers Citellus undulatus, an important food item for Imperial Eagles, have begun their winter hibernation. Thus it may be that the start of the Imperial Eagles' migration coincides with the disappearance of a major food source.

In this study, siblings migrating independently used the same migration flyway, while flyways were different between families. It has been observed on migration routes that juvenile Imperial Eagles do not migrate with parent birds (M. Krasnoshtanova, pers. comm.). Thus the use of the same migration flyway is not likely to be a behaviour learned from the adults. There is a possibility that siblings migrate by the same flyways because they use the same landmarks for navigation, such as rivers or mountains, but in this study they changed direction while in featureless desert and steppe areas, which does not support the idea that juveniles rely on landmarks to navigate. Rather, it suggests genetically based migration direction in juvenile eagles. There are many studies that suggest genetically based migration direction (reviewed in Baker 1984), including that of Bald Eagles (McClelland et al. 1996). This study seems to support the "genetically based hypothesis" and, furthermore, that genetically based migration directions were different between families.

\section{Acknowledgements}

We thank M. Krasnoshtanova, Yang Xiaojun, for information, and Simba Chan, Kazuji Fukui Jason Minton for discussion of ideas that led to this work and for helpful comments on earlier drafts. The PTTs for the project were donated by NTT.

\section{References}

ARGOS, Inc. (1992) User Manual. Toulouse, France: Service Argos.

Baker, R. R. (1984) Bird navigation: the solution of a mystery? Cambridge, U.K.: Cambridge University Press.

Belik V. P. and Galushin V. M. (1999) Population structure of the Imperial Eagle range in the northern Eurasia. Pp. 129-139 in Imperial Eagle: distribution, population status and conservation perspectives within Russia. Moscow: Russian Bird Conservation Union (Threatened Birds series, vol. 1).

BirdLife International (2000) Threatened birds of the world. Barcelona and Cambridge, U.K.: Lynx Edicions and BirdLife International.

Hallmann, B. (1996) The decline of the Imperial Eagle Aquila heliaca in Greece. Pp. 439442 in B-U. Meyburg and R. D. Chancellor, eds. Eagle studies. Berlin, London and Paris: World Working Group on Birds of Prey.

Haraszthy, L., Bagyura, J., Szitta, T., Petrovits, Z. and Viszló, L. (1996) Biology, status and conservation of the Imperial Eagle Aquila heliaca in Hungary. Pp. 425-428 in B-U. Meyburg and R. D. Chancellor, eds. Eagle studies. Berlin, London and Paris: World Working Group on Birds of Prey.

McClelland, B. R., McClelland, P. T., Yates, R. E., Caton, E. L. and McFadzen, M. E. (1996) Fledging and migration of juvenile Bald Eagles from Glacier National Park, Montana. J. Raptor Res. 30: 79-89. 
Meyburg, B.U. and Lobkov, E. G. (1994) Satellite tracking of a juvenile Steller's Sea Eagle Haliaeetus pelagicus. Ibis 136: 105-106.

Meyburg, B.U. and Meyburg, C. (1998) Satellite tracking of Eurasian raptors. Torgos 28: $33-48$.

Meyburg, B-U., Haraszthy, L., Meyburg, C. and Vizló, L. (1995) Satellite and ground tracking of a young Imperial Eagle Aquila heliaca: break-up of the family and dispersal. Vogelwelt 116: 153-157 (In German).

Nagendran, M., Higuchi, H. and Sorokin, A. G. (1994) A harnessing technique to deploy transmitters on cranes. Pp. 57-6o in H. Higuchi and J. Minton, eds. The future of cranes and wetlands. Tokyo: Wild Bird Society of Japan.

Petrov, T., Iankov, P., Darakchiev, A. et al. (1996) Status of the Imperial Eagle Aquila heliaca in Bulgaria in the period between 1890 and 1993. Pp. 429-434 in B.-U. Meyburg and R. D. Chancellor, eds. Eagle studies. Berlin, London and Paris: World Working Group on Birds of Prey.

Ryabtsev V. V. (1984) Ecology and conservation of Aquila heliaca in Pre-Baikal Region. Rev. Leningrad State Univ. 9(2): 20-27. (In Russian.)

Ryabtzev V. V. (1997) Imperial Eagle on Baikal. Hunting Huntery 7: 12-14. (In Russian.)

Ryabtsev V. V. (1998) The Imperial Eagle: bird of Baikal Legends. Irkutsk: Institute of Geography, Siberian Branch, Russian Academy of Sciences.

Ryabtsev V. V. (1999) The Imperial Eagle in Siberia. Pp. 54-61. In Imperial Eagle: Distribution, population status and conservation perspectives within Russia. Moscow: Russian Bird Conservation Union (Threatened Birds series, vol. 1).

Ueta, M., Sato, F., Lobkov, E. G. and Mita, N. (1998) Migration route of White-tailed Sea Eagles Haliaeetus albicilla in northeastern Asia. Ibis 140: 684-686.

Ueta, M., Sato, F., Nakagawa, H. and Mita, N. (2000) Migration routes and differences of migration schedule between adult and young Steller's Sea Eagles Haliaeetus pelagicus. Ibis 142: 35-39.

Vetrov, V. (1996) Status of the Imperial Eagle Aquila heliaca in Ukraine between 1897 and 1993. Pp. 435-438 in B.U. Meyburg and R. D. Chancellor, eds. Eagle studies. Berlin, London and Paris: World Working Group on Birds of Prey.

Wood, P. B., Collopy, M. W. and Sekerak, C. M. (1998) Postfledging nest dependence period of Bald Eagles in Florida. J. Wildl. Manage. 62: 333-339.

\section{MUTSUYUKI UETA}

Research Center, Wild Bird Society of Japan. 2-35-2 Minamidaira, Hino, Tokyo 191-0041, Japan. E-mail:mj-ueta@netlaputa.ne.jp

\section{VITALIY V. RYABTSEV}

Pribaikalsky National Park. Box 185, Irukutsk, 664049, Russia. E-mail: pribpark@angara.ru

Received 18 August 2000; revision accepted 20 December 2000. 